\title{
INTRODUCTION: VARIETIES OF SOCIOLOGY UNDER STATE SOCIALISM
}

\author{
Matthias Duller \\ University of Graz \\ Centre for Advanced Study Sofia \\ Mikołaj Pawlak \\ University of Warsaw
}

Viewed from afar, the political situations of the countries of Central and Eastern Europe under communist rule appear to have been roughly the same. It may thus seem obvious that the experiences of sociologists - and their institutional and epistemological situations - were also the same. But when we look more closely, it turns out that due to diverse national prewar traditions, the different natures of socialist regimes, and the power of links to Western sociology, conditions were much more diverse than might have been expected. In this issue of Stan Rzecry (State of Affairs) we bring together the writings of scholars from Poland, the Czech Republic, Belarus, Hungary, Romania, Albania, and Sweden to explore the diversity and similarity of sociology in these countries in terms of sociologists' roles, attitudes toward Marxism as a live tradition and official ideology, the development of concepts, the inclination to engage in empirical research, and so on. The inspiration came from three sessions organised by Matthias Duller, an editor of this issue, at the Interim Conference of the ISA Research Committee on the History of Sociology "Monuments, Relics, and Revivals" held in Warsaw in June 2016.

The present special issue is devoted to the history of sociology in Eastern Europe under state socialism. Most of the articles that follow deal with specific aspects of sociology in one or more countries; one article presents a framework for thinking about the topic in general. Here in the introduction we will place the subject in the context of social sciences beyond the socialist orbit.

The stunning rise of the social sciences after the end of the Second World War is not only interesting to social scientists for self-reflective pur- 
poses but is a historical phenomenon worth studying in its own right (compare Backhouse \& Fontaine 2010, 2014). The social sciences were elevated in connection with the global movement championing the sciences as the dominant and only legitimate knowledge system (Drori et al. 2003). While the centre of scientific knowledge undoubtedly moved from Europe to North America, the expansion of the science system was not just a simple process of diffusion from North America outwards but was a reaction to the challenges of the post-war era everywhere in the world.

Two of these challenges are of particular importance for the social sciences: the unparalleled pace of modernisation, and the Cold War, a military and cultural confrontation of competing "systems" with different answers to modernisation. Both have been discussed at great length in studies on the history of the social sciences in the Western world. Although it is obvious that the former Eastern bloc was affected by modernisation and the Cold War to at least the same degree as the West, such discussions in its regard are extremely rare. This special issue is intended to help fill the gap.

Modernisation, societal transformation, and the position of men and women in the modern world engendered the intellectual predisposition to make human affairs a matter of systematic inquiry, and provided a favoured object of study: from Comte to Marx and the founding fathers in the late nineteenth and early twentieth centuries, sociology has involved the study of modernity. On a global level, however, modernity's institutional "take-off" - to use a famous metaphor from modernisation theory - occurred only after the end of the Second World War. Then practically all societies, from "first world" capitalist democracies to "second world" socialist societies and "third world" postcolonial states, invested heavily in economic growth, industrialisation, social welfare, and, of course, the science and education that were supposed to provide the knowledge for these developments. The number of countries with a national science-policy organisation, for example, rose from less than twenty in the 1930s to over ninety in 1990 (Drori et al. 2003: 3). Most importantly, worldwide the university system expanded dramatically. The average number of students per 100,000 inhabitants rose from 160 in 1920 to 3,446 in the year 2000 (Fleck 2011:14-15) - a more than twenty-fold increase. Research and teaching personnel increased at a similar rate.

The same period was marked by the military and ideological confrontation of East and West, or of socialism versus capitalism. Over the past two decades there has come to be a burgeoning literature on how the Cold War influenced the social sciences not only in terms of institutional ex- 
pansion but also on the level of ideas (see e.g., Engerman 2010; Gilman 2016; Isaac 2007, 2011; Isaac \& Bell 2012; Simpson 1998; Solovey \& Cravens 2012). While a large number of studies describe the emergence of academic fields such as rational choice theory (Amadae 2003), game theory (Erickson 2015), modernisation theory (Gilman 2003; Latham 2011), and international relations (Guilhot 2011) in the context of the Cold War, only recently has research expanded to include the socialist countries of the Eastern bloc and the channels of communication between East and West (Boldyrev \& Kirtchik 2016). To connect the discussion of the social sciences under socialism with the literature of Cold War social science would be a very fruitful undertaking, because it would help to distinguish the modes of political influence and interference in the social sciences that are typical of autocratic regimes from those that also appear in democracies.

The social sciences under state socialism are commonly viewed with a focus on the totalitarian aspects of the situation: the instrumentalisation of the social sciences for ideological legitimisation; propaganda; censorship; and coercion (e.g., Keen \& Mucha 2004). This view assumes that the natural role of the social sciences is to evaluate social realities critically, and the social sciences' position is thus perverted under a regime that claims the exclusive right to interpret those realities for itself.

The restrictions the authoritarian regimes imposed upon the social sciences were undoubtedly severe and diminished those disciplines' scientific and social potential. But reducing the story to the opposition between political regimes (seen only as suppressors of social science knowledge) and social scientists (in latent or open opposition to the regimes) is a historical construction that might please the self-image of liberal intellectuals today but leads to other aspects being overlooked. Polish sociologists are especially proud that many of them adopted anti-regime positions. In other countries of the region - for instance, in Czechoslovakia and Hungary sociologists were also strongly engaged in political opposition and in some cases had to pay the price of being expelled from academia or forced to emigrate. Yet no such fundamental opposition can be observed in Albania, Bulgaria, the German Democratic Republic, or Romania.

As with the notion of varieties of capitalism we can thus talk about varieties of socialism: diverse modes of the political implementation of Marxism-Leninism, and, in our case, the disparate architecture of the social sciences in communist countries. The socialist states were transforming from Stalinism in the 1950s to other forms of state socialism. The divergence between these forms was especially visible in the degree of openness of 
intellectual debates in different countries at different points in time. None of the regimes were monolithic: there were factions in the communist parties and academia; intellectuals disagreed over how to interpret Marxism, socialism, and the social realities.

Most importantly, the totalitarianism-focused view tends to ignore the dilemma facing even the most repressive communist regimes: they needed reliable expertise and learned reflection about their political projects while at the same time they feared feeding independent and potentially dissident or revisionist political thought. Even during the Stalinist period, when the term "sociology" was banned and declared a bourgeois science, the study of society advanced, either in the form of historical materialism or under other names. During the thaw period, sociology was reintroduced to universities in some countries. Often, communist regimes consciously decided to help develop the social sciences, for the simple reason that the authorities thought such knowledge was needed in their societies. Some social scientists did indeed become critical intellectuals and dissidents; the vast majority did not, but adapted to the realities and produced research within the confines of what was possible.

Drori et al. (2003: 199) argue that communist scientific expansion was almost entirely driven by the natural sciences, while the social sciences were kept at a minimum. They base their judgment on an analysis of citations from an international database, which was likely incomplete. Looking at two state socialist societies, Yugoslavia and the German Democratic Republic (GDR), a completely different picture emerges. In the academic year 1965-1966 almost half of the students in "liberal" Yugoslavia (46\%) studied in the humanities and social sciences (UNESCO 1968: 43). In the GDR - an example of particularly tight dictatorship throughout its existence the SED leadership invested heavily in the social sciences, rather than suppressing them, with the goal of constructing a loyal intelligentsia (Connelly 1997). New scholarships and early career programmes were introduced in the late 1940s and early 1950s under direct party control. Around $60 \%$ of the beneficiaries were from the social sciences and humanities (Duller et al. 2018; Jessen 1999: 56-59). This indicates that the socialist regimes, certainly no less than Western democracies, felt an acute need for social-science knowledge and actively invested in its expansion. The relation between the nascent social sciences and the regimes differed strongly between countries and periods: in the GDR, for instance, sociologists were loyal intellectual extensions of the Communist Party; in Yugoslavia, there was relative tolerance for critical intellectuals; and in Hungary and Poland in the 1980s 
the social sciences often had a dissident inclination. In looking at each of these countries, the complex dynamics in the relation become obvious. There were various phases of greater openness, such as in Poland after 1956, in Czechoslovakia in the years before 1968, and in Romania during the early Ceaușescu years, but such periods were often followed by conservative backlashes in the name of "normalisation" or reconsolidation.

The aim of this special issue is thus to present empirical studies and to counter the conventional assumption that state socialism created the same conditions for sociological inquiry in all countries of the Eastern bloc.

Ideally, comparative studies are needed to advance our understanding of how political conditions and intellectual histories in the social sciences are related to each other. So far, most comparative efforts in the history of the social sciences have proceeded by assembling case studies (usually national ones) and by leaving the comparisons implicit and up to the reader. The exceptions to the rule are Voř́šsek $(2008,2012)$ and Koleva (2018), and for the West, Fourcade (2009). The lack of comparisons is unfortunate, but is likely due to a more general lack of empirical studies from which meaningful comparisons can be drawn.

Recently, an important source for the history of sociology in a large number of countries has been the Sociology Transformed series published by Palgrave Macmillan. Along with studies on sociology in many other regions, it currently features three studies on Eastern Europe (Bucholc 2016; Skovajsa \& Balon 2017; Titarenko \& Zdravomyslova 2017).

The current issue of Stan Rzeczy provides empirical studies on the varieties of conditions in which sociology existed under state socialism, in a way that promotes comparisons.

Why do we use the term "state socialism"? Because it is a good descriptor of the evolving political systems of countries ruled by communist parties. While the governing of these countries was driven by communist ideology, it was the web of institutions, the authorities at all different levels - in a word, the state - that shaped socialist societies more than anything else. The same political conditions also determined the shape of the social sciences in each of the countries. Intellectually, Marxism influenced the social sciences enormously, being the base of the official state ideology. The institutional settings, however, were more important, as they allowed social scientists to manoeuvre within the limits of official discourse with different degrees of freedom. Basic material conditions, such as access to literature, travel, conferences, and tighter or looser webs of censorship, had a more profound impact on social scientists' intellectual output than 
did the intellectual tradition of Marxism. As it turns out, serious Marxist scholarship was often a tool used to criticise Communist Party rule and was associated with dissident scholars rather than with conformists, who deemed lip service to Marxism sufficient.

We hope this issue will throw some light on the diversity of intellectual life in Central and Eastern Europe. The subject is important because the academic institutions formed in the period of state socialism still constitute the organisational base for the social sciences in the region, and many authors and ideas from this period still inspire younger generations of sociologists. Other ideas came to be forgotten in the period after the breakup of the system, but some are now being revived.

Communism in Central and Eastern European countries was a project of radical modernisation. Sociology, as a study of modern society, was deeply interested in this project, and rapid industrialisation and urbanisation were fascinating topics of inquiry. Yet, under the influence of Marxism as the official state ideology, certain research subjects were hard to approach. In many instances, social reality was not changing along the lines assumed by the doctrine. The key problem was change in the social structure. According to the doctrine, societies under state socialism should be transforming into classless societies. Yet social stratification seemed to persist. In some countries, revealing such research findings or even asking such research questions could be dangerous. In less harsh political systems, persons writing about social stratification struggled to reconcile the theory and the results. One of the outcomes was a very interesting sociology of social stratification, which was developed by Polish scholars such as Włodzimierz Wesołowski.

The elites and sociologists of Central and Eastern Europe defined their societies as peripheral societies engaged in catching up with the West. Indeed, state socialism was a grand project of modernisation and of escaping the peripheral position. Yet Eastern and Central European sociologists continued to perceive their societies as peripheral and looked to the cultural centre for theories to help them understand those societies. Depending on how closed the intellectual life of a given country was, this could be more or less easy - or nearly impossible. In Poland after 1956 sociologists had the opportunity to travel to the USA. They applied the theories they encountered there and also quite quickly adopted survey research techniques. What is also important in the context of Central and Eastern Europe is that quite a large body of theoretical works were translated into Polish. In other countries, as is interestingly described in this issue by Andrei Dudchik, 
the diffusion of Western sociological theories was possible via the trick of criticising bourgeois science. Authors made ceremonial use of historical materialism while discussing other theoretical frameworks.

However, this issue also teaches us not to treat Marxism solely as the official ideology of the communist countries. Marxism was revised and in some cases served as a useful framework for explaining and understanding the social processes in Central and Eastern Europe. It cannot be forgotten that the accusation of revisionism was a very dangerous tool in political debates. Still, some sociologists managed to construct interesting and inspiring interpretations of Marxism. The example of Polish Marxism-influenced sociology is discussed in this issue in the article by Maciej Gdula.

Since the fall of communism, communist regimes have conventionally been described as hostile to their societies. This is true: human rights were violated and before 1989 the Central and Eastern European states could by no means be called democracies. Nevertheless, we also have to admit that there were certain areas of social progress under state socialism. Thus dividing matters into black and white would seem to be an oversimplification, and yet the question that is often asked about sociologists is whether they were on the side of the state or of society during this time. Some were active (and some merely passive) members of communist parties, while others engaged in research on political mobilisation and joined the political opposition.

The present special issue of Stan Rzeczy is divided into four sections: sociology in Central and Eastern Europe; national sociologies; research, concepts, and perspectives; and reviews. The first paper, by Georges Mink, is a section on its own because it is the only paper that attempts a general characterisation of sociology in Central and Eastern Europe under socialism. It is based on a number of interviews the author conducted with sociologists in Poland, Hungary, Czechoslovakia, and the USSR during the 1980s. Although, as we argued above, such a perspective is only part of the story of sociology under state socialism and is close to the totalitarianismfocused view, the article provides rich insights into the lives and thinking of a cohort of sociologists and delivers an explicit conceptual discussion of the different roles sociologists played vis-à-vis state power.

The section titled "National Sociologies" discusses sociologies in four very different academic contexts: Romania, Poland, Belarus, and Albania. Stefan Bosomitu covers the entire history of Romanian sociology under socialist rule and places it in the context of political history. Among other things, the article shows the importance of individual figures such as Mi- 
ron Constantinescu (a former sociologist and later influential member of the communist regime, who played the key role in re-establishing the sociological discipline after 1965, see also Bosomitu 2014). In addition, Bosomitu provides an instructive discussion about the continuity of the strong pre-war tradition of Romanian sociology.

In her essay on the phases of sociology's development under communist rule in Poland, Agnieszka Kolasa-Nowak concentrates on the issue of modernisation. According to her, sociology has developed in parallel with changes in the regime. She distinguishes three phases in the history of Polish sociology under state socialism: first, it was a social laboratory for structural changes; then it became interested in social engineering (i.e., the sociotechnics project was developed); and in the 1980s it turned to critical analysis of the communist system. Yet Kolasa-Nowak claims that Polish sociology under state socialism was consistent in its main focus on catching up with the imagined modernised world.

Andrei Dudchik's article is particularly interesting as little has been written about sociology in Belarus. Dudchik presents two types of struggles in which the founding fathers of Belarusian sociology engaged. The first was the struggle for independence from philosophy. The second concerned the independence of sociology in Belarus from Soviet sociology. Belarus was just one of the USSR's sixteen republics. Sociology in Belarus was conducted in Russian and was influenced by trends from Moscow and Leningrad. Yet, as it departed from philosophy for empirical research, it focused mainly on local experience.

In an article entitled "The Autonomisation of the Cultural Field in Late Socialist Albania and the Emergence of Early Sociological Research" Sokol Lleshi and Teuta Starova address the issue of Albania's unique experience with sociology and attempt to compare it to the experience of other countries of the region. This is a very interesting case study, as Enver Hoxha's model of state socialism was one of the most radical in Europe, and sociology did not have much opportunity to develop there.

The section entitled "Research, Concepts, and Perspectives" consists of four articles: on sociological inquiries in Czechoslovakia, Hungary, Poland, and Sweden. The paper by Piotr Filipkowski, Judit Gárdos, Éva Kovács, and Vera Szabari compares the sociologies of lifestyle developed in the 1970s in Poland and Hungary. A very interesting finding of these authors is that although research on lifestyles in the two countries was conducted independently, there are striking similarities in the assumptions and approaches that were utilised in studying Hungarians and Poles. 
The sociology of lifestyle is also discussed by Michal Kopeček in his paper on applied sociology in Czechoslovakia. The sociology of lifestyle, next to the sociology of industry, was employed there in the project of building a socialist society. Kopeček demonstrates how sociological inquiries that supported the official scientific and technological revolution were developed in parallel with shadow and critical studies of the same aspects of Czechoslovak society. This study shows how sociology was involved in the "construction" of society under state socialism and how it also easily became involved in the "construction" of society under the neoliberal project after 1989.

In "The Warsaw School of Marxism" Maciej Gdula compares the achievements of Warsaw-based, Marxist-oriented sociologists with those of the famous Warsaw School of the History of Ideas. According to Gdula, the school of sociological inquiry created by Julian Hochfeld and his disciples cannot be captured by the dichotomy between official Marxism and revisionist Marxism. Hochfeld and his disciples were engaged on a truly empirical research program oriented towards improving society.

The article by Sven Eliaeson is distinct from other works included in the issue because it approaches our topic from the outside. In an exposition reaching back to late medieval times, Eliaeson unfolds the history of the concept of civil society in Sweden both as a "real" historical object of study and as an analytical tool for the study of a real object. Contrasting the Swedish concept with the very different meaning of "civil society" in 1980s Poland, the article provides an extremely original perspective on how sociological thinking - often far beyond the awareness of sociologists themselves - is dependent on historical conditions.

This issue also contains seven book reviews (works published in German, English, and Polish).

With the exception of Sven Eliaeson's article on the Swedish model of civil society, the present special issue is restricted to state socialism in Central Eastern Europe. State socialism, though, has existed in many other parts of the world. We certainly need more research on sociology under state socialism in Asia or in Cuba: sociology is developing very rapidly in China, for example. This issue proves that sociology is useful in understanding various types of societies. Yet it also provides material for understanding how various political conditions and worldviews influence sociological thinking. State socialism was an extreme case, but the study of extreme cases often proves helpful in understanding social processes. Zdeněk Konopásek (2000) claimed that understanding communist Czechoslovakia 
was a good way to understand any modern society. In Western liberal democracies there are also social scientists who justify the social order and those who are marginalised because of their critical stances. In the extreme case of state socialism these processes are more visible and methodologically easier to describe. Thanks to the papers collected in this issue we can understand how political and structural factors shape the minds of social scientists.

Bibliography:

/// Amadae S.M. 2003. Rationalizing Capitalist Democracy: The Cold War Origins of Rational Choice Liberalism, University of Chicago Press.

/// Amadae 2016. Prisoners of Reason: Game Theory and Neoliberal Political Economy, Cambridge University Press.

/// Backhouse R.E., Fontaine P., eds. 2010. The History of the Social Sciences since 1945, Cambridge University Press.

/// Backhouse R.E., Fontaine P., eds. 2014. A Historiography of the Modern Social Sciences, Cambridge University Press.

/// Boldyrev I., Kirtchik O. 2016. “On (Im)permeabilities: Social and Human Sciences on Both Sides of the "Iron Curtain," History of the Human Sciences, vol. 29(4-5), pp. 3-12.

/// Bosomitu Ș. 2014. Miron Constantinescu: O Biografie, Humanitas.

/// Bromley P., Meyer J.W. 2015. Hyper-Organization: Global Organizational Expansion, Oxford University Press.

/// Brunnbauer U., Kraft C., Schulze Wessel M., eds. 2011. Sociology and Ethnography in East-Central and South-East Europe: Scientific Self-Description in State Socialist Countries, Oldenbourg Wissenschaftsverlag.

/// Bucholc M. 2016. Sociology in Poland: To Be Continued? Palgrave Macmillan.

/// Connelly J. 1997. "Ulbricht and the Intellectuals," Contemporary European History, vol. 6(3), pp. 329-359.

/// Drori G.S., Meyer J.W., Ramirez F.O., Schofer E. 2003. Science in the Modern World Polity: Institutionalization and Globalization, Stanford University Press. 
/// Duller M., Fleck C., Schögler R.Y. 2018. “Germany: After the Mandarins," [in:] Shaping Human Science Disciplines: Institutional Developments in Europe and Beyond, eds. C. Fleck, M. Duller, V. Karády, Palgrave Macmillan.

/// Easton D., Gunnel J.G., Stein M.B., eds. 1995. Regime and Discipline: Democracy and the Development of Political Science, University of Michigan Press.

/// Engerman D.C. 2010. "Social Science in the Cold War," Isis, vol. 101(2), pp. 393-400.

/// Erickson P. 2015. The World the Game Theorists Made, The University of Chicago Press.

/// Fleck C. 2011. A Transatlantic History of the Social Sciences: Robber Barons, the Third Reich and the Invention of Empirical Social Research, Bloomsbury Academic.

/// Fourcade M. 2009. Economists and Societies: Discipline and Profession in the United States, Britain, and France, 1890s to 1990s, Princeton University Press.

/// Gilman N. 2003. Mandarins of the Future: Modernization Theory in Cold War America, Johns Hopkins University Press.

/// Gilman N. 2016. "The Cold War as Intellectual Force Field," Modern Intellectual History, vol. 13(2), pp. 507-523.

/// Guilhot N., ed. 2011. The Invention of International Relations Theory: Realism, the Rockefeller Foundation, and the 1954 Conference on Theory, Columbia University Press.

/// Isaac J. 2007. “The Human Sciences in Cold War America," The Historical Journal, vol. 50(3), pp. 725-746.

/// Isaac J. 2011. "Introduction: The Human Sciences and Cold War America," Journal of the History of the Behavioral Sciences, vol. 47(3), pp. 225-231.

/// Isaac J., Bell D. 2012. "Introduction,” [in:] Uncertain Empire: American History and the Idea of the Cold War, eds. J. Isaac, D. Bell, Oxford University Press, pp. 3-16.

/// Jessen R. 1999. Akademische Elite und kommunistische Diktatur: Die ostdeutsche Hochschullehrerschaft in der Ulbricht-Ära, Vandenhoeck \& Ruprecht.

/// Keen M.F., Mucha J., eds. 1994. Eastern Europe in Transformation: The Impact on Sociology, Greenwood Press. 
/// Keen M.F., Mucha J., eds. 2003. Sociology in Central and Eastern Europe: Transformation at the Dawn of a New Millennium, Praeger.

/// Keen M.F., Mucha J., eds. 2004. "Sociology in Central and Eastern Europe in the 1990s: A Decade of Reconstruction," European Societies, vol. 6(2), pp. 123-147.

/// Koleva S. 2018. Totalitarian Experience and Knowledge Production: Sociology in Central and Eastern Europe, 1945-1989, Brill.

/// Konopásek Z. 2000. "Reflexive Autobiographies: Interpreting the East - Understanding the West," [in:] Our Lives as Database: Doing a Sociology of Ourselves - Czech Social Transitions in Autobiographical Research Dialogues, ed. Z. Konopásek, Karolinum (Charles University Press), pp. 281-298.

/// Latham M.E. 2011. The Right Kind of Revolution: Modernization, Development, and U.S. Foreign Policy from the Cold War to the Present, Cornell University Press.

/// Simpson C., ed. 1998. Universities and Empire: Money and Politics in the Social Sciences during the Cold War, The New Press.

/// Skovajsa M., Balon J. 2017. Sociology in the Czech Republic: Between East and West, Palgrave Macmillan.

/// Solovey M., Cravens H., eds. 2012. Cold War Social Science: Knowledge Production, Liberal Democracy, and Human Nature, Palgrave Macmillan.

/// Titarenko L., Zdravomyslova E. 2017. Sociology in Russia: A Brief History, Palgrave Macmillan.

/// UNESCO. 1968. Science Policy and the Organization of Scientific Research in the Socialist Federal Republic of Yugoslavia. "Science Policy Studies and Documents," vol. 9, UNESCO.

/// Voř́šek M. 2008. "Antagonist, Type, or Deviation? A Comparative View on Sociology in Post-War Soviet Europe," Revue d'bistoire des Sciences Humaines, vol. 18, pp. 85-113.

/// Vořrišek M. 2012. The Reform Generation: 1960s Czechoslovak Sociology from a Comparative Perspective, Kalich. 